\title{
Maturity and batch fecundity of the European hake (Merluccius merluccius, Linnaeus, 1758) in the eastern central Atlantic
}

\author{
HAMMOU EL HABOUZ ${ }^{1}$, LAURA RECASENS ${ }^{2}$, SOUAD KIFANI ${ }^{3}$, \\ ABDELLATIF MOUKRIM ${ }^{4}$, ABDELLAH BOUHAIMI ${ }^{4}$ \\ and SALAHEDDINE EL AYOUBI ${ }^{1}$ \\ ${ }^{1}$ Institut National de Recherche Halieutique (INRH), Centre Régional d'Agadir, BP 5221, CP 80004, QI, Agadir, Maroc. \\ E-mail: helhabouz@yahoo.fr \\ ${ }^{2}$ Institut de Ciències del Mar de Barcelona (ICM-CSIC). Passeig Marítim 37-49, 08003 Barcelona, Catalonia, Spain. \\ ${ }^{3}$ Institut National de Recherche Halieutique (INRH), 2, Rue Tiznit, Casablanca, Maroc. \\ ${ }^{4}$ Université Ibn Zohr, Faculté des Sciences, Département de Biologie, Laboratoire Eaux et Environnement, Agadir, Maroc.
}

\begin{abstract}
SUMMARY: The reproductive biology of the European hake (Merluccius merluccius, Linnaeus, 1758) was studied on the eastern central Atlantic Moroccan coast from November 2001 to December 2003. The sex ratio was close to 1:1 for the specimens with a total length of less than $45 \mathrm{~cm}$. European hake spawned all year round, though two spawning peaks were recorded with a certain interannual variability: the first and main peak in winter and a secondary intermittent peak in summer. Length at first maturity was estimated as $28.6 \mathrm{~cm}$ and $33.8 \mathrm{~cm}$ total length for males and females, respectively. These values are closer to Mediterranean than Atlantic hake values. The mean batch fecundity was 299872 eggs ind $^{-1}$. The relative batch fecundity was estimated as 228 eggs per gram of gutted weight. Batch fecundity increased proportionally with fish length and weight. The batch fecundity of European hake in the Moroccan Atlantic area is higher than that in northern Atlantic and northwestern Mediterranean areas.
\end{abstract}

Keywords: Merluccius merluccius, sex ratio, reproductive cycle, length at first maturity, fecundity.

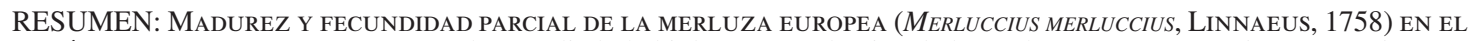
AtLÁNTICo ORIENTAl CENTRAL. - Se ha estudiado la biología reproductiva de la merluza europea (Merluccius merluccius, Linnaeus, 1758) en la zona central del Atlántico Oriental de la costa de Marruecos durante el período de noviembre de 2001 a diciembre de 2003. La proporción sexual fue cercana a 1:1 para los individuos de talla total menor de $45 \mathrm{~cm}$. La merluza europea se reproduce durante todo el año. Se han detectado dos picos de puesta con una cierta variabilidad interanual: el primero y más importante en invierno y otro pico secundario intermitente en verano. La talla de primera madurez se estimó en $28.6 \mathrm{~cm}$ y $33.8 \mathrm{~cm}$ de longitud total para machos y hembras respectivamente. Estos valores son más cercanos a los observados para la merluza en el Mediterráneo que a los del Atlántico. La fecundidad parcial media fue de 299872 huevos ind ${ }^{-1}$. La fecundidad parcial relativa se estimó en 228 huevos por gramo de hembra referido al peso eviscerado. La fecundidad parcial se incrementó proporcionalmente a la longitud y peso del pez. La fecundidad parcial de la merluza europea en el área atlántica de Marruecos, muestra valores más altos que en las áreas del Atlántico situadas más al norte y del NW Mediterráneo.

Palabras clave: Merluccius merluccius, proporción sexual, ciclo reproductivo, talla de primera madurez, fecundidad.

\section{INTRODUCTION}

Information on reproductive biology, especially fecundity and egg production, is fundamental in the study of the biology and population dynamics of fish species
(Hunter et al., 1992; Murua and Saborido-Rey, 2003). It is the basis for quantifying reproductive capacity at the individual and population levels of a fish species (Murua et al., 2006). Some assessment models use information on reproductive variables such as age or 
length at maturity, fecundity and spawning frequency to estimate fish biomass. Annual changes in these variables could affect the stock productivity and produce variability in fish recruitment (Macchi et al., 2004).

In Morocco, the European hake (Merluccius merluccius, Linnaeus, 1758) is found along the Mediterranean coast and in the Atlantic from the Strait of Gibraltar to 21 degrees north (INRH, 2002). This species is found over all types of bottoms from the coast down to $1000 \mathrm{~m}$ depth (FAO, 2006). Juveniles (total length $<20 \mathrm{~cm}$ ) abound from the coast to $500 \mathrm{~m}$ depth, while bigger individuals are found further offshore in bathymetric strata between 500 and $1000 \mathrm{~m}$ (Benchoucha et al., 2006; El Habouz et al., 2007). The European hake migrates for reproduction and food. Large reproductive individuals concentrate at the edge of the continental shelf to spawn (FAO, 1986).

The Moroccan Atlantic population of European hake is considered as a single stock. It is the only hake species caught by the coastal fishery. The fleet that operates on this species is composed of 450 trawlers and 20 longliners (FAO, 2006). Results from the recent assessments of the FAO Working Group on demersal resources in the CECAF area carried out in Gambia in November 2007 indicate that the European hake stock is overexploited. The Working Group therefore recommended reducing current fishing effort so that catch levels do not exceed 3500 tonnes, and banning fishing during the months of June and July to preserve juvenile individuals.

Due to its commercial importance, a series of biological studies on Merluccius merluccius has been carried out in Atlantic areas. Its growth and reproductive biology have been studied on the eastern Moroccan Atlantic coast by Maurin (1954), Goñi (1983), Ramos et al. (1990, 1991), El Habouz (1995) and Lahrizi (1996). Growth and maturity have also been studied in Iberian Atlantic waters (Piñeiro and Sainza, 2003, DomínguezPetit et al., 2008b ), while the reproductive strategy and spawning activity of hake have been researched in the North Atlantic (Murua and Saborido-Rey, 2003; Domínguez-Petit et al., 2008a) and the Bay of Biscay (Murua and Motos, 2006; Murua et al., 2006). The southern part of the Atlantic distribution for this species extends to $22^{\circ} 35^{\prime} \mathrm{N}$, where it cohabits with the black hake (Merluccius senegalensis, Cadenat 1950) species from $29^{\circ} 21^{\prime} \mathrm{N}$ (FAO, 1986); therefore, there may be additional interest in studying the reproductive parameters in this part of the geographical distribution. In addition, there are still few studies that deal with all the reproductive parameters of this species. In fact, the only estimates for fecundity are from the Atlantic Iberian Peninsula (Bay of Biscay and Galicia) (Murua et al., 2006) and the NW Mediterranean (Catalan and northern Tyrrhenian Seas) (Recasens et al., 2008).

The aim of the present work is to study the reproductive potential of Merluccius merluccius for the first time in the Moroccan Atlantic by identifying spawning peaks, determining the size at first maturity and calculating the fecundity parameters.

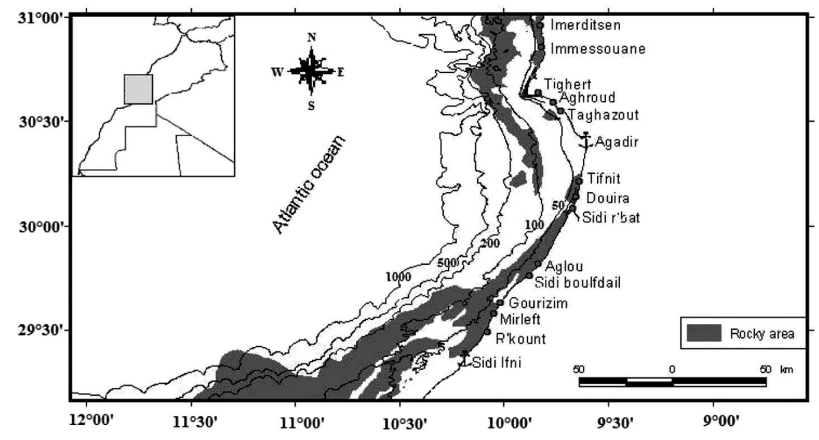

FIG. 1. - Map showing the study area between Immesouane $\left(30^{\circ} 50^{\prime} \mathrm{N}, 09^{\circ} 49^{\prime} \mathrm{W}\right)$ in the north and Sidi Ifni $\left(29^{\circ} 21^{\prime} \mathrm{N}, 10^{\circ} 11^{\prime} \mathrm{W}\right)$ in the south.

\section{MATERIALS AND METHODS}

European hake samples were collected monthly in the eastern central Atlantic from November 2001 to December 2003. Samples were taken in Agadir port from trawl landings. These trawlers operate in the area located between Immessouane (30 $\left.50^{\prime} \mathrm{N}, 09^{\circ} 49^{\prime} \mathrm{W}\right)$ in the north and Sidi Ifni $\left(29^{\circ} 21^{\prime} \mathrm{N}, 10^{\circ} 11^{\prime} \mathrm{W}\right)$ in the south (Fig. 1), between 100 and $150 \mathrm{~m}$ depth (El Habouz et al., 2009). A total of 1332 specimens were sampled, ranging from 17 to $71 \mathrm{~cm}$ total length (Table 1). Individuals below $17 \mathrm{~cm}$ were not analysed due to the difficulty of sex identification at macroscopic level. For each specimen the following parameters were taken:

total length (TL) to the lowest half $\mathrm{cm}$, total weight (TW) and gutted weight to $0.1 \mathrm{~g}$, and gonad and liver weight to $0.01 \mathrm{~g}$. The maturity stage was determined for $M$. merluccius using the maturity scale for partial spawners (Holden and Raitt, 1974). European hake individuals of both sexes were considered mature from stage III (Table 2).

\section{Sex ratio}

Sex ratio was defined as the proportion of males and females by length class in all the samples.

TABLE 1. - Sampling data on M. merluccius in the central Moroccan Atlantic.

\begin{tabular}{lcc}
\hline Period & Num. ind. & $\begin{array}{c}\text { Length range } \\
\text { Total length (cm) }\end{array}$ \\
\hline Nov.-Dec. 01 & 166 & $17-49.5$ \\
Jan.-Feb. 02 & 124 & $20.5-71$ \\
Mar.-Apr. 02 & 127 & $17-65.5$ \\
May-Jun. 02 & 98 & $19-43$ \\
Jul.-Aug. 02 & 83 & $21-53$ \\
Sept.-Oct. 02 & 81 & $20-56$ \\
Nov.-Dec. 02 & 88 & $19-49$ \\
Jan.-Feb. 03 & 88 & $20-42$ \\
Mar.-Apr. 03 & 146 & $20-63$ \\
May-Jun. 03 & 67 & $22-34$ \\
Jul.-Aug. 03 & 107 & $19-69$ \\
Sept.-Oct. 03 & 81 & $21-45$ \\
Nov.-Dec. 03 & 76 & $20-39.5$ \\
& & $17-71$ \\
Total & 1332 & \\
\hline
\end{tabular}


TABLE 2. - Maturity scale for partial spawners (Holden and Raitt, 1974).

\begin{tabular}{ll}
\hline Stage State & \multicolumn{1}{c}{ Description } \\
\hline I Immature & $\begin{array}{l}\text { Ovaries and testes occupy about a third of the length of the abdominal cavity. Ovaries pinkish and translucent. } \\
\text { Testes whitish. Eggs invisible to the naked eye. }\end{array}$ \\
II Maturation and recovery & $\begin{array}{l}\text { Ovaries and testes occupy about half the length of the abdominal cavity. Ovaries pinkish and translucent. } \\
\text { Testes whitish, more or less symmetrical. Eggs invisible to the naked eye. }\end{array}$ \\
III Advanced Maturing & $\begin{array}{l}\text { Ovaries and testes occupy about two thirds of the length of the abdominal cavity. Ovaries pinkish-yellow and } \\
\text { grainy. Testes white to cream. No transparent or translucent eggs visible. }\end{array}$ \\
IV Mature (ripening) & $\begin{array}{l}\text { Ovaries and testes occupy about two thirds to the entire length of the abdominal cavity. Ovaries pink-orange } \\
\text { with superficial blood vessels visible. Eggs mature and transparent. Testes white, creamy and soft. } \\
\text { Ovaries and testes shrink to about half the length of the abdominal cavity. Walls loose. Ovaries can contain } \\
\text { the remains of opaque, ripe eggs in disintegration. Eggs darkened or translucent. Testes flaccid and bloodshot. }\end{array}$ \\
\hline
\end{tabular}

\section{Gonadosomatic index (GSI) and hepatosomatic index (HSI)}

The GSI was calculated as a percentage of the gonad weight in relation to the total weight of the fish. The HSI was calculated as the percentage of liver weight in relation to total weight of the fish.

\section{Length at first maturity $\left(\mathbf{L}_{\mathbf{5 0}}\right)$}

Length at first maturity was defined as the length at which $50 \%$ of the specimens developed ripe gonads for the first time, and was estimated considering specimens in stages higher than stage I for both males and females. $\mathrm{L}_{50}$ was estimated for 546 females ranging from 20 to $71 \mathrm{~cm}$ TL and for 558 males ranging from 20 to $45 \mathrm{~cm}$ TL.

Length at first maturity was estimated by means of a logistic model fitted to the percentage of mature specimens per length class (Yeates, 1974) with the equation:

$$
f(x)=\frac{1 . M}{1+a \cdot e^{-b x}}
$$

where $f(x)$ represents the percentage of mature specimens, $M$ the maximum value of $f(x), x$ the length, $a$ and $b$ are parameters of the curve, and $e$ the natural logarithm base.

\section{Fecundity}

Batch fecundity is defined as the total number of eggs released by a mature female. It was calculated according to the gravimetric method based on the relationship between ovary weight and oocyte density (Murua et al., 2003). Only hydrated ovaries without recent postovulatory follicles were used to calculate batch fecundity (Hunter and Macewicz, 1985), and only oocytes with a diameter greater than $750 \mu \mathrm{m}$ were hydrated (Murua et al., 1998). The hydrated oocytes of 3 subsamples ( 0.1 to $0.3 \mathrm{~g}$ each) per ovary of a mature female were taken randomly from three parts (anterior, middle and posterior) of the right and left ovary lobes. The number of oocytes in each $100-\mu \mathrm{m}$ diameter size class was counted using a binocular with a micrometer. A total of 30 ovaries was analysed. The average value was calculated, expanded to the total ovary weight and expressed as the number of oocytes per ovary, using the following equation:

$$
F=\frac{\sum \frac{O i}{W i}}{n} W_{\text {ovary }},(\text { Murua et al., 2003) }
$$

where $F$ represents the total number of eggs in the ovary, $W_{\text {ovary }}$ is the ovary weight (in grams), Wi the oocyte sample weight, $O i$ the total number of eggs in the ovary sample, and $n$ the number of ovary samples.

The relative batch fecundity was calculated as the number of hydrated oocytes per gram of gutted weight. Relationships between batch fecundity, total length and gutted weight of the fish were estimated by fitting power functions.

The oocyte size-frequency distribution of a standard female of $45 \mathrm{~cm}$ TL was studied through subsequent maturity stages (II, III and IV). The abundance of oocytes was expressed as a percentage of the 100 $\mu \mathrm{m}$ diameter classes. Three females were used for these calculations. For each maturity stage, the oocyte distribution corresponded to an individual fish.

\section{RESULTS}

\section{Sex ratio}

Out of a total of 1332 specimens ranging from 17 to $71 \mathrm{~cm} \mathrm{TL}, 51.3 \%$ were females between 17 and $71 \mathrm{~cm}$ TL and $48.7 \%$ were males between 17 and $45 \mathrm{~cm}$ TL. The sex ratio calculated in each length class of European hake individuals is shown in Figure 2.

To compare the sex proportions in the length interval [17 to 45], a $\chi^{2}$ test was applied with contingency tables and with 29 length classes $(n=29$, d.f. $=28)$. The proportions of males (50.5\%) and females (49.5\%) show no significant differences from a ratio of $1: 1$ at $P$ $=0.05$. However, all the specimens with a TL greater than $45 \mathrm{~cm}$ were females (Table 3 ). 


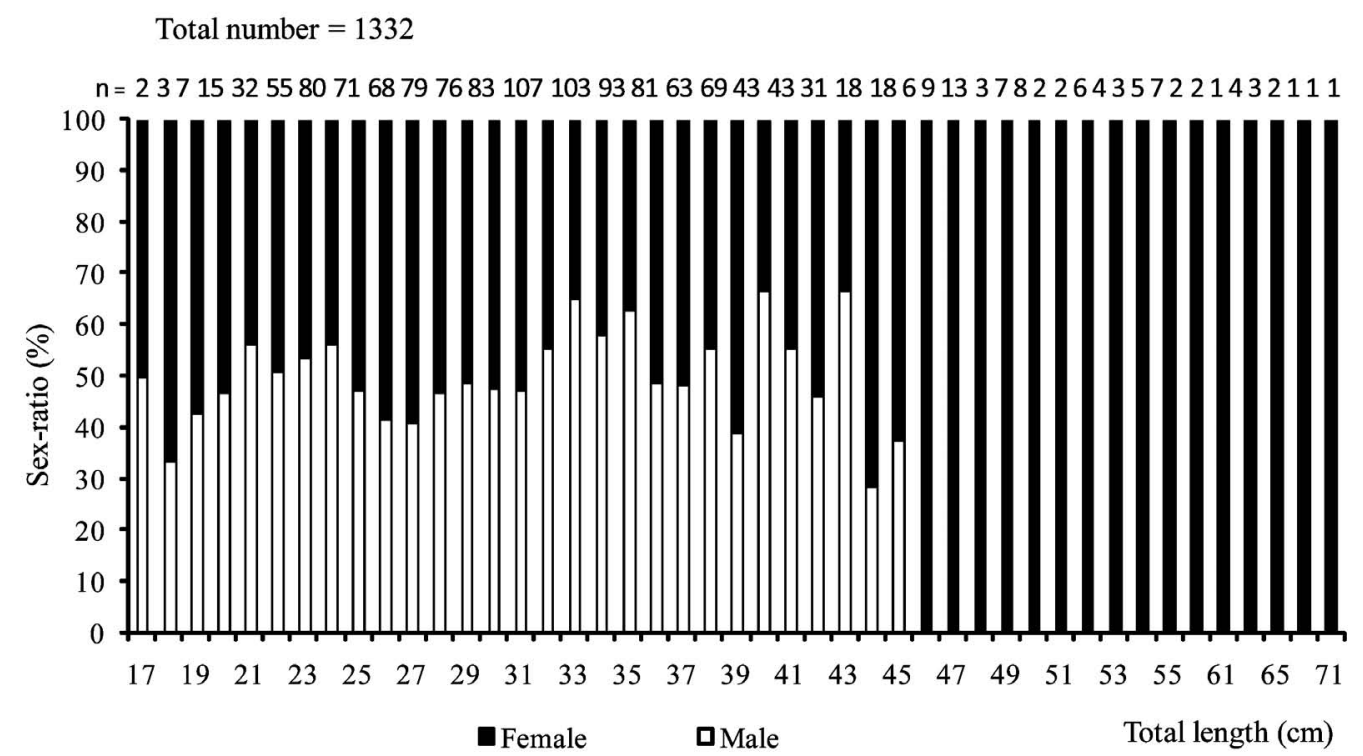

FIG. 2. - M. merluccius sex ratio by length class.

TABLE 3. - Sex ratio of $M$. merluccius by length interval, tested with an $\chi^{2}$ analysis at $P=0.05 \%$

\begin{tabular}{lcccccc}
\hline Length interval & Number of individuals & Males & Females & (d.f) & Observed $\chi^{2}$ & Theoretical $\chi^{2} P=0.05$ \\
\hline $17-45 \mathrm{~cm}$ & 1286 & $50.5 \%$ & $49.5 \%$ & 28 & 24 & 41.3 \\
$>45 \mathrm{~cm}$ & 46 & $0 \%$ & $100 \%$ & - & & \\
\hline
\end{tabular}
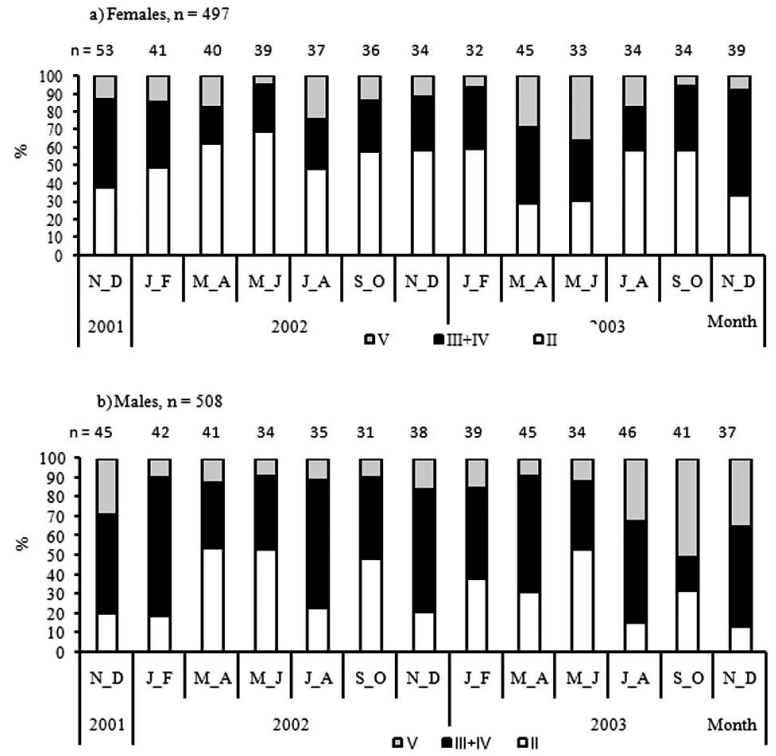

FIG. 3. - Bimonthly percentages of M. merluccius in different maturity stages during the sampling period. II, maturing and recovery; $\mathrm{III}+\mathrm{IV}$, advanced maturing + spawning; V, post-spawning. (a) Females; (b) Males.

\section{Spawning cycle}

The bimonthly evolution of the percentage of maturity stages showed that mature (III+IV) and postspawning (V) females were present all year round. The same phenomenon was found for males in terms

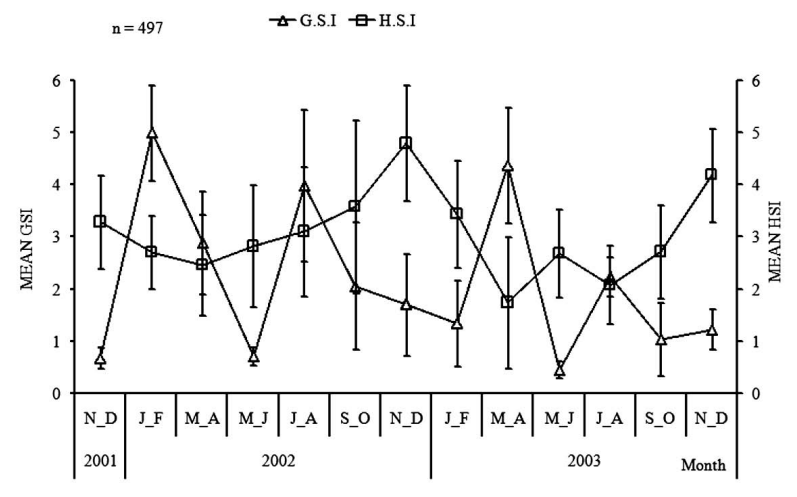

FIG. 4. - The bimonthly evolution of the mean gonadosomatic (GSI) and hepatosomatic (HSI) indexes for M. merluccius females during the sampling period.

of presence of individuals in the mature (III+IV) and post-spawning $(\mathrm{V})$ stages during the sampling period (Fig. 3a, b). Consequently, females and males of $M$. merluccius in the study area were reproductively active throughout the entire year.

The bimonthly evolution of the GSI and HSI of the European hake for a period of 26 months is shown in Figure 4 for females and in Figure 5 for males.

According to the evolution of the females GSI (Fig. 4), in 2002 the main spawning peak occurred in winter (January-February) and a secondary peak in summer (July-August). However, in 2003 the winter spawning peak occurred later, at the end of winter and start of spring (March-April), and the secondary GSI peak, 


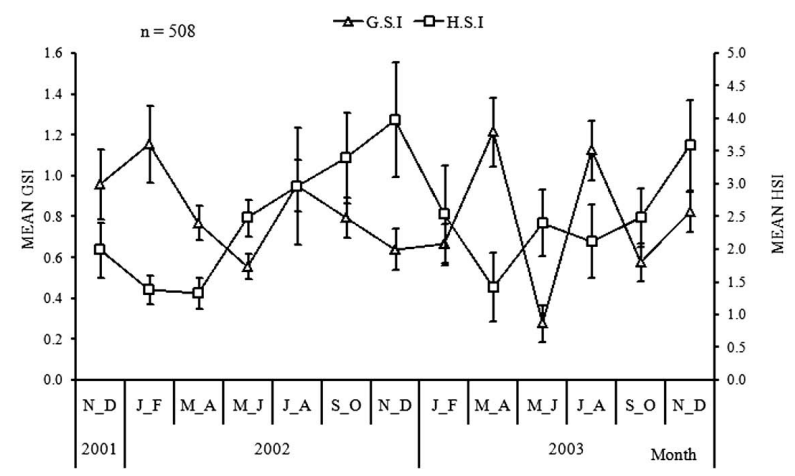

FIG. 5. - The bimonthly evolution of the mean gonadosomatic (GSI) and hepatosomatic (HSI) indexes for M. merluccius males during the sampling period.
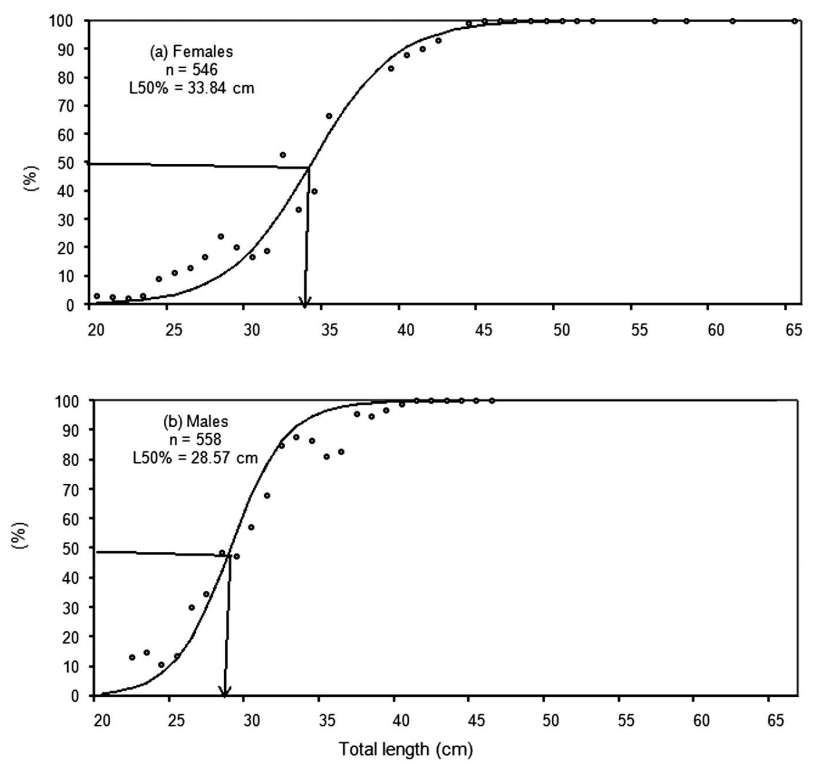

FIG. 6. - M. merluccius length at first maturity for a) females and b) males.

which occurred in July-August, was too low to be considered a real spawning peak. The HSI had a main peak in November-December in both years (Fig. 4). This peak preceded the spawning peaks (GSI) which took place in January-February 2002 and March-April 2003. The reserves accumulated in the liver in the HSI peaks are mobilized for use during oogenesis in the ovaries.

Figure 5 shows two spawning peaks for European hake males in each year. These two peaks took place in January-February and July-August in 2002 and in March-April and July-August in 2003. The evolution
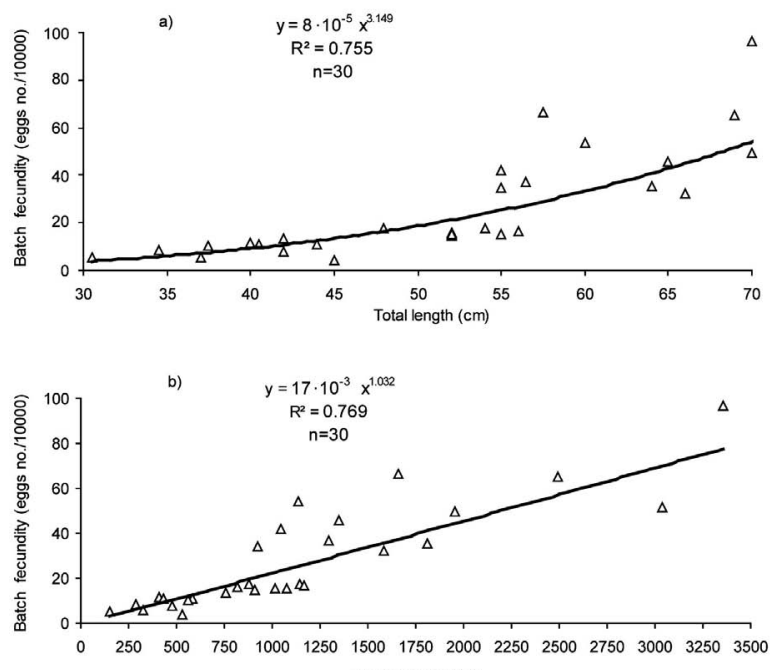
Gutted w eight $(g)$

FIG. 7. - Relationships between batch fecundity and a) total length $(\mathrm{cm})$, and b) female gutted weight $(\mathrm{g})$.

of the HSI shows that the maximum accumulation of reserves in the liver occurred in November-December 2002 and 2003 before the main spawning period.

\section{Length at first maturity}

Length at first maturity was estimated at $33.8 \mathrm{~cm}$ for females and $28.6 \mathrm{~cm}$ for males (Fig. 6a, b). The length at which $75 \%$ of individuals are mature was $36.8 \mathrm{~cm}$ for females and $30.6 \mathrm{~cm}$ for males. While the length at which $25 \%$ of individuals are mature was $30.8 \mathrm{~cm}$ for females and $26.5 \mathrm{~cm}$ for males.

\section{Fecundity}

The batch fecundity estimates ranged from 39962 for a female of $45 \mathrm{~cm}$ TL to 965770 for a female of 70 $\mathrm{cm}$ TL. The average batch fecundity was calculated as 299872 hydrated oocytes per female.

The average relative batch fecundity was 228 eggs $\mathrm{g}^{-1}$ (female gutted weight) and ranged from 75 to 400 eggs $\mathrm{g}^{-1}$ (Table 4).

Our results indicate that the relationships between batch fecundity and fish length (TL) and gutted weight $\left(\mathrm{W}_{\mathrm{g}}\right)$ are best described by

$$
\begin{gathered}
\mathrm{F}=8 \cdot 10^{-5} \mathrm{~L}^{3.149}\left(\mathrm{n}=30, \mathrm{r}^{2}=0.755\right) \text { and } \\
\mathrm{F}=17 \cdot 10^{-3} \mathrm{~W}_{\mathrm{g}} .032\left(\mathrm{n}=30, \mathrm{r}^{2}=0.769\right)
\end{gathered}
$$

Batch fecundity correlated positively with fish length and fish gutted weight (Fig. 7a,b).

The oocyte size-frequency distribution through the subsequent mature stages of M. merluccius showed the

TABLE 4. - Batch fecundity values for M. merluccius.

\begin{tabular}{lcccc}
\hline & Average & Standard deviation & Minimum & Maximum \\
\hline $\begin{array}{l}\text { Batch fecundity (no. eggs /fish) } \\
\begin{array}{l}\text { Relative batch fecundity } \\
\text { (no. eggs g-1(female gutted weight ) }\end{array}\end{array}$ & 299872 & 249692 & 39962 & 965770 \\
\hline
\end{tabular}



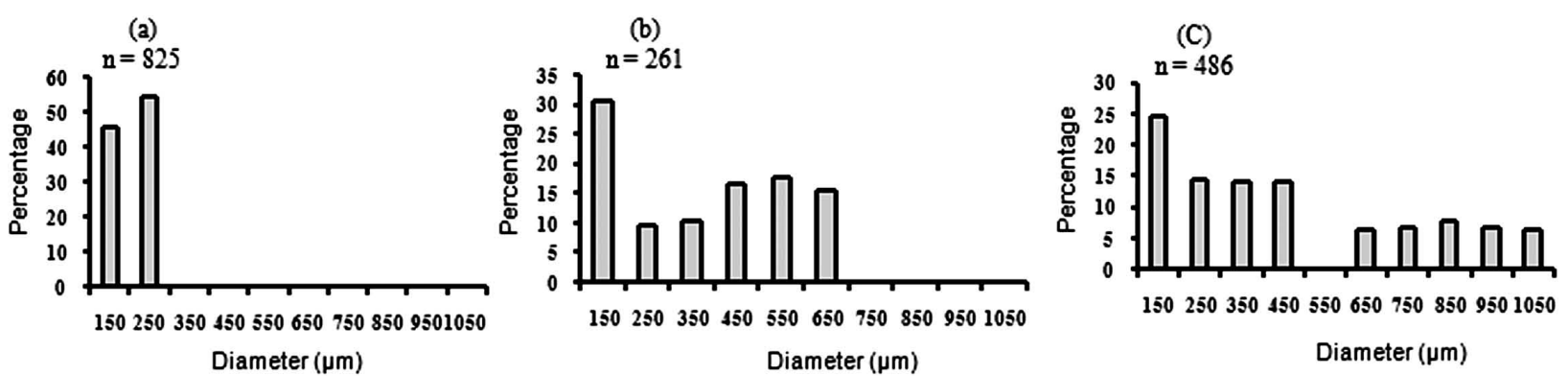

FIG. 8. - Oocyte size-frequency distributions (percentage abundance per $100 \mu \mathrm{m}$ diameter size classes) of a standard female European hake of $45 \mathrm{~cm}$ in subsequent maturity stages: a) virgin and recovery, b) In maturation and c) Mature (ripening).

continued presence of small oocytes (150 to $250 \mu \mathrm{m}$ diameter). Hydrated oocytes with a diameter higher than $750 \mu \mathrm{m}$ appeared in the mature and prespawning stage before ovulation. (Fig. 8a,b,c).

\section{DISCUSSION}

The evolution of the sex ratio in the length class interval [17 to 45] shows that the sex ratio was close to $1: 1$. Only females were found over $45 \mathrm{~cm} \mathrm{TL}$. A similar result was observed by Piñeiro and Sainza (2003) in Iberian Atlantic waters corresponding to ICES divisions IXa and VIIIc. This could be due to the differences in the different growth rates of the two sexes. Indeed, a recent study of the growth of European hake using tagging and recapture techniques (Mellon-Duval et al., 2010) shows that from the second year of life, females grow faster than males.

The spawning cycle of the European hake was studied according to the bimonthly evolution of the GSI and HSI. As the GSI is an index of gonadal maturity, a higher index shows that the gonads are developing, and a lower value indicates the end of the spawning period (Lahaye, 1972). During maturation and when vitellus is accumulated, the HSI decreases rapidly (Lahaye, 1972; Billard, 1979). During the life cycle of fish, the HSI peak usually precedes the GSI peak.
The European hake is reproductively active for almost the entire year, with certain interannual variability (Recasens et al., 1998); therefore, the annual evolution of the two indexes is not as clear as in species with a shorter spawning season. The winter spawning season has been observed previously in the Moroccan Atlantic (Ramos et al., 1990, 1991; El Habouz, 1995); however, other authors (Maurin, 1954) have found the hake spawning season to be from December to early summer. Our results show that there was a main spawning peak in winter and a secondary one in summer in 2002; however, in 2003, the winter spawning season was delayed one month and took place in late winter and early spring, and the secondary summer spawning peak was too low to be considered a real peak. Therefore, the European hake spawning cycle in this area also shows certain interannual variability, as a winter peak was observed in the two studied years but a summer peak was only observed in the first year of the study. Two peaks have also been observed in winter and summer in the CECAF area (Cervantes and Goñi, 1986), while a maximum spawning peak was observed from January to March on the north Atlantic Spanish coast (Perez and Pereiro, 1981, 1985; Piñeiro and Sainza, 2003) and in the Bay of Biscay (Murua and Motos, 2006).

In the Mediterranean Sea, Bouhlal (1973) observed a maximum spawning peak in winter and two other

TABLE 5. - Size at first maturity $(\mathrm{cm})$ for European hake from different geographic areas.

\begin{tabular}{|c|c|c|c|c|}
\hline Author (year) & Study Area & $\mathrm{L}_{50}$ male & $\mathrm{L}_{50}$ female & Methodology used \\
\hline Present study & $\begin{array}{l}\text { eastern central Moroccan } \\
\text { Atlantic coast }\end{array}$ & 28.6 & 33.8 & $\begin{array}{l}\text { Length at which } 50 \% \text { of individuals are } \\
\text { mature using a logistic equation }\end{array}$ \\
\hline EL Habouz (1995) & central Moroccan Atlantic & 35.0 & 46.5 & $\begin{array}{l}\text { Length at which } 50 \% \text { of individuals are } \\
\text { mature using a cumulative frequency }\end{array}$ \\
\hline Lahrizi (1996) & northern Moroccan Atlantic & 37.8 & 41.1 & $\begin{array}{l}\text { Length at which } 50 \% \text { of individuals are } \\
\text { mature using a cumulative frequency }\end{array}$ \\
\hline Piñeiro and Sainza (2003) & Iberian Spanish Atlantic & 32.8 & 45.4 & $\begin{array}{l}\text { Length at which } 50 \% \text { of individuals are } \\
\text { mature using a Logistic equation }\end{array}$ \\
\hline Domínguez-Petit et al. (2008b) & Iberian Atlantic & - & 46.0 & Logistic equation \\
\hline Domínguez-Petit et al. (2008b) & North Atlantic & - & 41.0 & Logistic equation \\
\hline Recasens et al. (1998) & Mediterranean Sea Gulf of Lions & 28.8 & 38.0 & $\begin{array}{l}\text { Length at which } 50 \% \text { of the specimens } \\
\text { have already matured at least once }\end{array}$ \\
\hline Recasens et al. (2008) & Catalan Sea & - & 35.8 & $\begin{array}{l}\text { Length at which } 50 \% \text { of individuals are } \\
\text { mature using a Logistic equation }\end{array}$ \\
\hline Recasens et al. (2008) & northern Tyrrhenian Sea & - & 35.1 & $\begin{array}{l}\text { Length at which } 50 \% \text { of individuals are } \\
\text { mature using a Logistic equation }\end{array}$ \\
\hline Bouaziz et al. (1998) & Region of Bou-Ismail (Alger) & 21.5 & 30.6 & $\begin{array}{l}\text { Length at which } 50 \% \text { of individuals are } \\
\text { mature calculated by the evolution of the } \\
\text { percentage of mature specimens }\end{array}$ \\
\hline
\end{tabular}


smaller peaks in spring and late summer in the Gulf of Tunis. In the Gulf of Lions a certain amount of interannual variability has been observed. In 1989 and 1990 the spawning period was in autumn, but the percentage of ripe females was always higher than 10-15\% during all the seasons in 1990 (Recasens et al., 1998).

The length at first maturity $\left(\mathrm{L}_{50}\right)$ was estimated in the present study as $28.6 \mathrm{~cm}$ for males and $33.8 \mathrm{~cm}$ for females. According to the Von Bertalanffy growth equation calculated from tagging and recapture data by De Pontual et al. (2006), the age at first maturity for hake would correspond to one year for males and one and a half years for females. In comparison with previous studies (Table 5), the $\mathrm{L}_{50}$ estimated for European hake in the Moroccan Atlantic dropped significantly after a time interval of about ten years. Indeed, using data collected from commercial fishery catches in 1992 , the $\mathrm{L}_{50}$ was estimated at 35 and $46.5 \mathrm{~cm}$ for males and females, respectively, in the central Moroccan Atlantic (El Habouz, 1995) and at $37.8 \mathrm{~cm}$ and $41.1 \mathrm{~cm}$ for males and females, respectively, in the north Moroccan Atlantic (Lahrizi, 1996). Overexploitation due to excessive fishing effort (FAO, 2010) could have caused the decrease in $\mathrm{L}_{50}$ observed for European hake. Moreover, the present first maturity sizes are lower than those recently reported in the northern Iberian Atlantic (Piñeiro and Sainza, 2003; Domínguez-Petit et al., 2008b). In our results, the $\mathrm{L}_{50}$ for females $(33.8 \mathrm{~cm})$ is close to values reported for the Catalan Sea and northern Tyrrhenian Sea, estimated respectively at $35.8 \mathrm{~cm}$ and $35.1 \mathrm{~cm}$ (Recasens et al., 2008); these values are also slightly lower than those observed 10 years previously (Recasens et al., 1998). The smallest values for these parameters are reported for the region of Bou-Ismail $(21.5 \mathrm{~cm}$ for males and $30.6 \mathrm{~cm}$ for females) (Bouaziz et al., 1998) but this could be due to differences in methodology used for parameters estimation. First sexual maturity is therefore not late in European hake. Males reach maturity at a smaller size and at an earlier age than females. It is clear that the $\mathrm{L}_{50}$ has decreased compared to values observed in previous years, which could be related to the overexploitation of the stock.

Since European hake is a batch spawner with indeterminate fecundity and asynchronous ovarian organization (Murua and Saborido-Rey, 2003), batch fecundity corresponds to the number of hydrated oocytes present in the ovary during the prespawning stage. The fecundity results presented in this study represent the first estimation of the reproductive potential of European hake in the Moroccan Atlantic area. The relative batch fecundity was estimated to be 228 eggs $\mathrm{g}^{-1}$ (gutted weight), which is higher than that estimated in the western Mediterranean (203 eggs g ${ }^{-1}$ ) (Recasens et al., 2008) and much higher than the 165 eggs g$^{-1}$ estimated in the Bay of Biscay (Murua et al., 1998; Murua et al., 2006). In comparison with other species of the genus Merluccius, the batch fecundity is higher than that of Merluccius gayi (125 eggs g $\left.{ }^{-1}\right)$ (Cerna and Oyarzun, 1998) and very much lower than the value estimated for Merluccius hubbsi (551 eggs $\mathrm{g}^{-1}$ ) (Macchi et al., 2004). However, there is both intra and interannual variability in the relative batch fecundity of M. merluccius (Murua et al., 2006). The mean batch fecundity of European hake in the Moroccan Atlantic area, estimated as 299872 eggs per female, was also higher than that estimated in northern Atlantic areas (220636 per female) (Murua and Motos, 2006) and the northwestern Mediterranean (150000 per female) (Recasens et al., 2008). The evolution of the batch fecundity by length and weight of European hake shows that the number of hydrated eggs per female increases with the length and weight.

Therefore, the results obtained in the present study clarify some aspects of the reproductive biology of $M$. merluccius on the eastern central Atlantic Moroccan coast and situate the reproductive parameters of this species at the southern end of its distribution range, closer to Mediterranean values than North Atlantic ones. A good knowledge of the reproductive strategy of M. merluccius will allow us to understand the recruitment mechanisms for this important commercial resource.

\section{ACKNOWLEDGEMENTS}

We would like to thank L. BHAR, J. RAFIK and M. YOUSRA who helped in sampling. We also thank the anonymous reviewers and the editor for their useful comments on the submitted manuscript and $\mathrm{K}$. Stonehouse for the English version. This study was supported by the INRH (Institut National de Recherche Halieutique) of Morocco.

\section{REFERENCES}

Benchoucha, S., H. El Habouz, A. Kalmouni, M. Naji and M. Yousra. - 2006. Principaux résultats de la campagne de prospection par chalutage de fond de la zone atlantique nord à bord du N/R «CHARIF AL IDRISSI», du 31mars au 18 juin 2007. Rapp. interne de l'I.N.R.H. Casablanca, Maroc.

Billard, R. - 1979. La gamétogenèse, le cycle sexuel et le contrôle de la reproduction chez les poissons téleosteens. Bull. Fr. Pisci. $\mathrm{N}^{\circ} 273$.

Bouaziz, A., R. Sermoud, F. DjabaliI and C. Maurin. - 1998. Reproduction du merlu Merluccius merluccius (linnaeus, 1758) dans la région de Bou-Ismaîl. CIHEAM Cah. Opt. Méd., 35: 109-117.

Bouhlal, M. - 1973. Le merlu des côtes nord de la Tunisie: Etude économique et biologique. Bull. Inst. Océanogr. Pêche Salambo, 2(4): 579-603.

Cerna, J.F. and C. Oyarzún. - 1998. Talla de primera madurez sexual y fecundidad parcial de la merluza común (Merluccius gayi, Guichenot 1848) del área de la pesquería industrial de la zona de Talcahuano, Chile Invest. Mar., Valparaíso, 26: 31-40.

Cervantes, A. and R. Goñi. - 1986. Contribución al conocimiento sexual, época de puesta y sex ratio de la merluza europea (Merluccius merluccius Linnaeus, 1758) de África occidental. FAO, COPACE/PACE. Ser. 86/33: 266-276.

De Pontual, H., A.L. Groison, C. Piñeiro and M. Bertignac. - 2006. Evidence of underestimation of European hake growth in the Bay of Biscay, and its relationship with bias in the agreed method of age estimation. ICES J. Mar. Sci., 63: 1674-1681.

Domínguez-Petit, R., A. Alonso-Fernández and F. Saborido-Rey. - 2008a. Reproductive strategy and oocyte recruitment process of European hake (Merluccius merluccius) in Galician shelf waters. Cybium, 32(2) suppl.: 317-318. 
Domínguez-Petit, R., M. Korta, F. Saborido-Rey, H. Murua, M. Sainza and C. Piñeiro. - 2008b. Changes in size at maturity of European hake Atlantic populations in relation with stock structure and environmental regimes. J. Mar. Syst., 71: 260-278.

El Habouz, H. - 1995. Etude de la biologie et la dynamique des populations du merlu blanc (Merluccius merluccius, Linnaeus 1758) débarqué par les chalutiers côtiers au port d'Agadir. Thèse de troisième cycle. Option Océanographie biologique. Univ. Ibn Zohr. Agadir. Maroc. Nº d18/95: 1-108.

El Habouz, H., S. Belkaid, B. Tarchiq, A. Kalmouni and A. Chaghif. -2007 . Principaux résultats de la campagne de prospection par chalutage de fond de la zone atlantique nord à bord du N/R «CHARIF AL IDRISSI», du 05 au 18 juin 2007. Rapport interne de l'I.N.R.H Casablanca, Maroc.

El Habouz, H., L. Bhar, J. Rafik and M. Yousra. - 2009. Etude de l'activité de pêche des chalutiers côtiers dans la zone Atlantique Centre Marocain: Exploitation et Cycles biologiques des principales espèces ciblées. Centre Régional de l'INRH à Agadir. Rapport interne.

FAO. - 1986. Rapport du premier Groupe de travail spécial sur les pêcheries de merlus et de crevettes profondes dans la zone nord du COPACE. COPACE/PACE SERIES 86/33. Rome, Italie.

FAO. - 2006. Rapport du Groupe de travail FAO/COPACE sur l'évaluation des ressources démérsales - sous groupe Nord. Saly, Sénégal, 14-23 septembre 2004. COPACE/PACE SERIES 06/68

FAO. - 2010. Rapport du Groupe de travail FAO/COPACE sur l'évaluation des ressources démérsales - sous groupe Nord. Banjul, Gambie, 6-14 novembre 2007.

Goñi, R. - 1983. Growth studies of European hake (Merluccius merluccius L.) from the northwest African shelf. ICES. C.M. 1983/G: 10. Demersal Fish Committee.

Holden, M.J. and D.F.S. Raitt. - 1974. Manuel des sciences halieutiques. Deuxième partie. Méthodes et recherches sur les ressources et leur application. Doc. Tech. FAO. Pêches Rev., 115(1): $223 \mathrm{p}$

Hunter, J.R. and B.J. Macewicz. - 1985. Measurement of spawning frequency in multiple spawning fishes. In: R. Lasker (ed.), An Egg Production Method for Estimating Spawning Biomass of Pelagic Fish: Application to the Northern Anchovy, Engraulis mordax, pp. 79-94. Washington, D.C., U.S. Department of Commerce.

Hunter, J.R., B.J. Macewicz, N.C.H. Lo and C.A. Kimbrell. - 1992. Fecundity, spawning and maturity of female Dover sole, Microstomus pacificus, with an evaluation of assumptions and precision. Fish. Bull., 90: 101-128.

INRH. - 2002. Ressources halieutiques: situation et niveau d'exploitation. Rapp. Inst. Nat. Rech. Hal.

Lahaye, J. - 1972. Cycles sexuels de quelques poissons plats des côtes de bretonnes. Rev. Trav. Inst. Pêches Marit., 36: 191-207.

Lahrizi, H. - 1996. Etude de la biologie de croissance et de reproduction du merlu blanc Merluccius merluccius (L. 1758) débarqué par les chalutiers au port de Casablanca. Thèse de troisième cycle. Univ. Mohamed V, Rabat, Maroc.

Macchi, G.J., M. Pájaro and M. Ehrlich. - 2004. Seasonal egg production pattern of the Patagonian stock of Argentine hake
(Merluccius hubbsi). Fish. Res., 67: 25-38

Maurin, C. - 1954. Les merlus du Maroc et leur pêche. Bull. Inst. Pêche Mar. Maroc. Casablanca, 2: 7-65.

Mellon-Duval, C., H. De Pontual, L. Métral and L. Quemener. 2010. Growth of European hake (Merluccius merluccius) in the Gulf of Lions based on conventional tagging. ICES J. Mar. Sci., 67: 62-70.

Murua, H. and L. Motos. - 2006. Reproductive strategy and spawning activity of the European hake, Merluccius merluccius (L.), in the Bay of Biscay. J. Fish. Biol., 69: 1288-1303.

Murua, H. and F. Saborido-Rey. - 2003. Female reproductive strategies of marine fish species of the North Atlantic. J. Northw. Atl. Fish. Sci., 33: 23-31.

Murua, H., L. Motos and P. Lucio. - 1998. Reproductive modality and batch fecundity of the european hake (Merluccius merluccius L.) in the bay of Biscay. CalCOFI Rep., 39: 196-203.

Murua, H., P. Lucio, M. Santurtún and L. Motos. - 2006. Seasonal variation in egg production and batch fecundity of European hake Merluccius merluccius (L.) in the Bay of Biscay. J. Fish. Biol., 69: 1304-1316.

Murua, H., G. Kraus, F. Saborido-Rey, P.R. Witthames, A. Thorsen and S. Junquera. - 2003. Procedures to estimate fecundity of marine fish species in relation to their reproductive strategy. $J$. Northw. Atl. Fish. Sci., 33: 33-54.

Pérez, N. and F.J. Pereiro. - 1981. First data on sexual maturation and sex-ratio of hake VIII C. And IX a. ICES C.M. 1981/G, 37.

Pérez, N. and F.J. Pereiro. - 1985. Aspectos de la reproducción de la merluza (Merluccius merluccius L.) de la plataforma gallega y cantábrica. Bol. Inst. Esp. Oceanogr., 2(3): 39-47.

Piñeiro, C. and M. Sainza. - 2003. Age estimation, growth and maturity of the European hake (Merluccius merluccius (Linnaeus, 1758) from Iberian Atlantic waters. ICES J. Mar. Sci., 60: 1086-1102.

Ramos, A., A. Cervantes and I. Sobrino. - 1990. Estudios biológicos sobre la merluza europea (Merluccius merluccius L. 1758) del área de CECAF. FAO. COPACE/PACE. Ser., 90/51, 155-177.

Ramos, A., I. Sobrino and Y.L. Fernández. - 1991. Biología de la merluza europea (Merluccius merluccius, L. 1758) de las costas de África nor-occidental. Act. Icong. Oceanogr. Y Rec. Mar. Atl. Oc. Las Palmas, 28-30 Nov. 1990

Recasens, L., A. Lombarte, B. Morales-Nin and G.J. Torres. - 1998 Spatiotemporal variation in the population structure of the European hake in the NW Mediterranean. J. Fish Biol., 53: 387-401.

Recasens, L., V. Chiericoni and P. Belcari. - 2008. Spawning pattern and batch fecundity of the European hake (Merluccius merluccius, Linnaeus, 1758) in the western Mediterranean. Sci. Mar., 72: 721-732.

Yeates, J. - 1974. An introduction to quantitative analysis in human geography. J. Yates and J.R. Belser (eds.), Mc Graw-Hill series in geography

Scient. ed.: P. Sartor.

Received April 19, 2010. Accepted November 24, 2010.

Published online April 11, 2011. 